\title{
Other Understanding Arrangements That Are Contrary to Pancasila in Law Number 16 of 2017
}

\author{
Tuti Herawati ${ }^{1}$; M.Ilwan; Kaharudin ${ }^{2}$ \\ ${ }^{1}$ Student of Magister Law Study Program, Mataram University, Indonesia \\ ${ }^{2}$ Lecture of Law Faculty Mataram University, Indonesia
}

http://dx.doi.org/10.18415/ijmmu.v6i5.1158

\begin{abstract}
This research was conducted to find out how other understanding arrangements that are contrary to Pancasila in Law No. 16 of 2017; and What are the criteria or objective measures of an understanding that are considered contrary to the Pancasila and which institution is competent in evaluating an understanding that is considered to be in conflict with the Pancasila. To be able to find an objective measure of "understanding that is contrary to Pancasila", several approaches can be used namely, first the Philosophical approach, which focuses on theoretical deepening of the rule of law with the core of the study explaining that an Act must emerge with the principle of concrete rules and is easily understood generally. Secondly, the Juridical approach which explains that the mention of the two last additional elements in the explanation of Article 59 paragraph 4 letter c of Law No. 16 of 2017. And third, a sociological approach that explains that to be able to find an objective measurement mechanism for "understanding contrary to Pancasila". In the provisions of the prohibition of Community Organizations contained in Article 59 of Law No. 16 of 2017 specifically related to "Understanding that is contrary to Pancasila", is very laden with nuances of social and moral values, therefore to be able to measure actions or understandings that are considered to be in conflict with it must be submitted to the judiciary in evaluating it.
\end{abstract}

Keywords: Arrangement; Understanding; Pancasila

\section{A. Introduction}

According to Defense Minister Ryamizard Ryacudu explained that there were four ideas that could potentially erode, threaten and even destroy the Pancasila as the Foundation of the Indonesian State at this time. Minister of Defense further said that the four understandings that would replace Pancasila; Liberal, Communist, Socialist and Radical Islam ${ }^{1}$. Meanwhile, according to the Coordinating Minister for Politics, Law and Human Rights, Djoko Suyanto emphasized the government's attitude towards understanding the Islamic State of Iraq and Syria or the Islamic State of Iraq and Syria (ISIS) which later

${ }^{1}$ Https://Www.Antaranews.Com/Berita/548438/Menhan-Jelaskan-Empat-Paham-Mengancam-Pancasila.Access on April 28,2018 
became the Islamic State (IS) ${ }^{2}$. He stressed that ISIS was not a matter of religion. But, the problem of ideology. And if it is associated with the state of Indonesia, the ideology of understanding ISIS is very contrary to the ideology of Indonesia, namely the ideology of the Pancasila and the Unitary State of the Republic of Indonesia.

Radicalism is a radical school or ideology of political order; understand or flow that demands social and political changes in a country hard. ${ }^{3}$ Basically, the term Radicalism is actually not an alien concept. In general, there are three trends which are indicative of radicalism. First, radicalism is a response to an ongoing condition, usually the response appears in the form of evaluation, rejection or even resistance. Problems that are rejected can be in the form of assumptions, ideas, institutions or values that are considered responsible for the sustainability of the rejected conditions. Second, radicalism does not stop at the effort of rejection, but continues to try to replace the order with another form of order. This characteristic shows that radicalism contains a program or worldview of its own.

Radicalists try hard to make the order replace the existing order. Thus, in accordance with the meaning of the word 'radic', a radical attitude presupposes a desire to fundamentally change things. is the strong belief of radicals about the truth of the program or ideology they carry. This attitude is at the same time coupled with the truth panafian of other systems that will be replaced in social movements, beliefs about the truth of the program or philosophy are often combined with ways of achieving that in the name of ideal values such as democracy or humanity. However, the strength of these beliefs can lead to the emergence of emotional attitudes among radicalists. Religious radicalism is actually a phenomenon that usually arises in any religion. Radicalism is very closely related to fundamentalism, which is marked by the return of society to the basics of religion. Fundamentalism is a kind of ideology that makes religion the basis of life for both society and individuals. Usually fundamentalism will be accompanied by radicalism and violence when the freedom to return to religion is hindered by the socio-political situation that surrounds society.

In order to maintain the stability of the country and all the blood of the Indonesian nation, the government triggered the statutory regulation by issuing Law Number 16 Year 2017 Establishing Government Regulation in Lie of Law Number 2 Year 2017 Concerning Amendments to Law Number 17 Year 2013 Concerning Community Organizations Become a law. This new law emerged to prevent understanding, ideology that threatened the diversity and unity of the Indonesian people. In terms of laws and regulations, the government feels that the Social Organization Law Number 17 of 2013 is no longer sufficient as a means to prevent the spread of ideologies or understandings that are in conflict with the Pancasila and the 1945 Constitution, both from substantive aspects related to norms, prohibitions and existing sanctions and legal procedures. This is considered to be an emergency or anxiety situation that forces the government to issue Government Regulations in lieu of Law Number 2 of 2017. Not long ago, the government re-enacted and ratified Government Regulations in lieu of Law Number 2 of 2017 becoming Law No 16 of 2017.

Even this Law Number 16 Year 2017, in one of its articles, states a definition of understanding that is contrary to Pancasila, In the Elucidation of Article 59 paragraph (4) letter C this Law states; What is meant by teachings that are contrary to Pancasila are atheism, communism or marxism, leninism, or other ideas aimed at replacing or changing Pancasila and the 1945 Constitution of the Republic of Indonesia. 1945 can be interpreted as an extension of teachings that could threaten the ideology and basis of the Indonesian state. However, the addition of phrases and definitions still seems biased, this is because until now there are no parameters regarding understanding that is in conflict with Pancasila and its relation to the life of democracy itself. On the one hand it is clear that it can effectively crack down on Community Organizations that want to undermine Indonesia, but on the other hand it is feared is an

\footnotetext{
${ }^{2} \mathrm{Http} / /$ Www.Tribunnews.Com/Nasional/2014/08/04/Tak-Sesuai-Pancasila-Pemerintah-Tolak-Aksespaham-Isis.

${ }^{3}$ Lihat, M. Zaki Mubarak, Geneologi Islam Radikal Di Indonesia, ( Jakarta :Lp3es, 2008).
} 
attempt by the government to silence the Social Organizations that are opposite the government due to the absence of parameters or indicators regarding understandings that conflict with the government.

Some of the explanations in the elements of article 59 above basically have an extension of meaning from those previously stipulated in Law No. 17 of 2013, because in the previous law there was no interpretation of understandings that were in conflict with Pancasila including those aimed at changing or changing the 1945 Constitution and Pancasila. Therefore the expansion of the definition explained formally in the explanation of article 59 paragraph (4) of Law No. 16 of 2017 is included in the gray norm area, because it is followed by an interpretation mechanism, as well as clear understanding boundaries that can be used as a reference for law enforcement in carrying out the mandate of the trade.

Based on the explanation above, this study is very interesting to study, because it is an actual and contemporary study that is still warm to be discussed in depth and lengthy, so it seems clear the problem map that will be presented. In summary, this paper will look for how other understanding arrangements that are contrary to Pancasila in the regulation of legislation, what is the criterion or measure of an understanding is said to be incompatible with Pancasila, which institution is competent to judge an understanding contrary to Pancasila.

\section{B. Results and Discussion}

\section{Other Understanding Arrangements That Are Contrary to Pancasila In Law Number 16 Year 2017}

In the Government Regulation in Lieu of Law Number 2 of 2017 there are a number of things that experienced a fundamental change from the previous arrangement in Law No. 17 of 2013, especially in the provisions of Article 59 concerning prohibitions for some social organizations.

In Article 59 paragraph (4) Government Regulation in Lieu of Law Number 2 of 2017, it explains that ${ }^{4}$ :

Community organizations are prohibited:

a. use the names, symbols, flags or symbols of organizations that have similarities in principle or in whole with the names, symbols, flags or symbols of separatist movements or banned organizations;

b. conduct separatist activities which threaten the sovereignty of the Unitary State of the Republic of Indonesia; and / or

c. adhere to, develop, and spread teachings or understandings that are contrary to Pancasila.

The prohibition phrase for Social Organizations to adhere to ideas that are contrary to Pancasila is regulated in the Government Regulation in Lieu of this Law, contained in Article 59 paragraph (4) letter $\mathrm{c}$.

If in Law No. 17/2013 the phrase understanding which is contrary to Pncasila becomes the core points contained in paragraph (4), but a different matter in the Government Regulation in Lieu of Law

\footnotetext{
${ }^{4}$ Government regulations in lieu of Law Number 2 Year 2017, Article 59 Paragraph (1) - Paragraph (4)
} 
No. 2 of 2017, the mention of phrases that are contrary to Pancasila becomes part of it in several points in paragraph (4).

If we look closely at the systematic arrangements in paragraph (4), there are fundamental things that become the main concepts of the prohibition, where previously the points stipulated in points $\mathrm{a}$ and $\mathrm{b}$ are regulated separately in paragraph (1) and paragraph (2) Article 59 Law Number 17 of 2013 but Government Regulation in Lieu of Law Number 2 of 2017 these points are integrated in paragraph (4). Which can be considered systematic arrangements as follows:

a. use the names, symbols, flags or symbols of organizations that have similarities in principle or in whole with the names, symbols, flags, or symbols of separatist movements or banned organizations (this prohibition focuses on Community Organizations in Indonesia so that there are no indications that the Social Organization is affiliated or become a sub-part of a Community Organization that has a separatist movement and threatens national custody);

b. conduct separatist activities which threaten the sovereignty of the Unitary State of the Republic of Indonesia (this prohibition is aimed at ensuring that all Community Organizations in Indonesia do not directly or indirectly carry out separatist activities which threaten the integrity of the nation); and / or

c. adhere to, develop, and spread teachings or understandings that are contrary to Pancasila (the prohibition of Community Organizations to carry out mental movements that attack the ideology of the nation which can be dangerous for the potential destruction of national unity).

The essence of the prohibition points regulated and integrated in paragraph (4) is specifically to talk about efforts to safeguard the integrity and integrity of the nation from the activities of prohibited Community Organizations, and to prohibit all actions that could threaten national unity and undermine the ideology of the Indonesian people.

Furthermore, in the elucidation of Article 59 paragraph (4) explains that ${ }^{5}$ :

a. Letter a

Quite clear.

b. Letter b

What is meant by "carrying out separatist activities" is an activity aimed at separating bagran from or the whole territory of the Unitary State of the Republic of Indonesia or controlling parts or the whole territory of the Unitary State of the Republic of Indonesia, both on the basis of ethnicity, religion, and race.

c. Letter c

What is meant by "teachings or understandings that are contrary to Pancasila" include teachings of atheism, communism/marxism-Leninism, or other ideas aimed at replacing/changing Pancasila and the 1945 Constitution of the Republic of Indonesia.

Objective Criteria or Measures for Understanding are Conflicted with Pancasila

\footnotetext{
${ }^{5}$ Elucidation of Article 59 of the Government Regulation in lieu of Law Number 2 of 2017
} 


\section{a. Philosophical Approach}

Explanation in Interpretation Methods and Conceptual Approaches

In general, grammatical interpretation is to interpret the words or terms in the laws and regulations in accordance with the rules of language (grammatical law) in force. For A. Pitlo, grammatical interpretation means, we try to capture the meaning of a text/regulation according to the sound of the words. This can be limited to something automatic, which is not realized, which we always do when we read, and the results of its interpretation can be deeper than the original text. A word can have various meanings, for example in legal language can mean different compared to social language. ${ }^{6}$

Grammatical interpretation occurs when in determining the meaning of the rule of law refers to the words used or parts of sentences based on everyday words or commonly used. ${ }^{7}$

In the Big Indonesian Dictionary the word "ubah" has meaning; to be different (different) from the beginning; exchange (switch, change) into something else; change (about direction) ${ }^{8}$. Whereas the word "mengubah" has meaning; making it different from the beginning: the intention arises for - bad habits; swapping shapes (color, appearance, etc.): surgery has - the pug's nose has become somewhat sharp; rearrange; sentence structure.

Furthermore, the word "ganti" has a meaning; something that is missing or lost, such as prosthesis, pampas: this coconut milk can be used for - milk; people who replace jobs, positions, etcetera; vice; successor: the deceased headman does not yet exist; I am - your father; change; exchange; move. While the word "replace" has meaning; swap (for others): give compensation (about goods): represent ${ }^{9}$.

So simply in the concept of the word word replace / change has the same meaning that is the existence of an action taken to change or exchange something with something else which is certainly not exactly the same as the original form.

Acts which have elements of replacing or changing the Pancasila must be interpreted as a whole not only as an effort to replace precepts for precepts because every precepts are an integral part of the precepts in the Pancasila.

This is based on the concept by the opinion of Prof. Dr. Kaelan, who stated that ${ }^{10}$ :

As a basic philosophy (Philosofische Groundslag), the Pancasila is not only as a result of consensus, but as a philosophical basis so that in the formulation of the precepts contained philosophical values contained therein.

Furthermore, according to the view of the Pancasila Basic Philosophy Theory, Prof.

Dr. Kaelan, further explained that ${ }^{11}$ :

The meaning of the precepts of Pancasila is a rounded and intact, possessing a hierarchical and pyramidal shape. Then the understanding of the precepts of the Almighty God is Humanity that is Just

\footnotetext{
${ }^{6}$ Jazim Hamidi, Hermeneutika Hukum, Uii Press, Yogyakarta, 2005, p. 53

${ }^{7}$ Peter Mahmud Marzuki, Pengantar Ilmu Hukum, Kencana Predana Media Group, Jakarta, 2009, p. 344

${ }^{8}$ Kamus Besar Bahasa Indonesia (KBBI) Online, Downloaded on April 3, 2019

${ }^{9}$ Ibid

${ }^{10}$ Ibid. p. 49

${ }^{11}$ Ibid. p. 52
} 
and Civilized, united in Indonesia, populist who is led by wisdom wisdom in consultation/representation and social justice for all Indonesian people.

Therefore, based on the above studies, a temporary conclusion can be drawn that:

First, understanding that is contrary to Pancasila or understood as intended to replace or change Pancasila, needs to be regulated regarding its prohibitions and sanctions because the effort to change the Pancasila means that it will have a major impact on the order of Indonesian national life as a whole, because in the Pancasila concept as the Philosopische Groundslag is interpreted as Pancasila as the position of Pancasila as a whole the basis of state philosophy, which means changing the foundation or foundation will change the entire building above it.

Second, an act or understanding aimed at changing/replacing Pancasila, must be interpreted as an action that changes all or part of the five precepts in the Pancasila, because changing just one precept means replacing all precepts in the Pancasila.

Third, the act or understanding which aims to change/replace Pancasila, must be interpreted as an action that changes one of the values of Pancasila, namely the concrete value of Pancasila or the abstract value of Pancasila or changing both values (concrete value and abstract value) of Pancasila. So in this concept applies the alternative-cumulative concept in its meaning.

Whereas acts which have the potential to change or amend the Constitution (1945 Constitution) must be interpreted as:

1. That the prohibition on understanding aimed at changing the 1945 Constitution is based on theoretical and conceptual considerations because the constitution is the basic law for the administration of a country, which means that arbitrary attempts to change the Constitution can have a long-standing effect on the running of the state system.

2. That understanding aimed at changing the 1945 Constitution, is understood as an effort to change the Preamble section along with the main points of thought in each art, and the Body (along with all its contents), transitional rules, and additional rules (both one and both).

3. That understanding aimed at changing the 1945 Constitution is interpreted as an understanding or action that wishes to change the 1945 Constitution illegally (both theoretically and juridicallyconstitutional). This means that the desired change of action is outside the conditions specified in the 1945 Constitution.

\section{b. Juridical Approach}

If we pay attention to the historical pattern of the formation of a Law on Social Organization between Law Number 17 of 2013 and Law Number 16 of 2017, there are several elements of expanding its understanding of "Understanding that is contrary to Pancasila". Which previously was only known in the understanding of "Understanding that is contrary to Pancasila" as forms of understanding that have been mentioned in detail in the explanation of the Act concerned, namely understanding in the form of atheism, communism/marxism-Leninism.

However, the meaning of the meaning of "understanding that is contrary to Pancasila" is in Law Number 16 Year 2017, that what is meant by "Understanding that is contrary to Pancasila" is not enough up to the elements as above but there are the addition of two elements namely "Understanding which aims to replace/change Pancasila" and "Understanding which aims to replace/change the 1945 Constitution". 
So that with the addition of the two elements above that are suspected then as a gap there will be multiple interpretations of the prohibited points for Community Organizations, which will certainly have an impact or result in the dissolution of a Community Organization. These additional elements are suspected of being used as a venue for abuse of power for the government or law enforcers in disbanding certain Community Organizations that are considered dangerous to the State even though some of the elements are not categorized as Prohibited Community Organizations, such as the HTI dissolution mechanism which the author has explained in the previous sub-chapter.

Therefore, then to be able to measure the objective limits of the meaning of "Understanding that is contrary to Pancasila" referred to in Law Number 16 Year 2017, it is not enough to use a philosophical and theoretical approach or in other words it is not enough just to explain the elements contained in the sound of the article and its explanation, but the writer wants to restore the formal mechanism of this latest regulation as the previous regulation in Law Number 17 of 2013.

So that the mention of the last two additional elements in the explanation of Article 59 paragraph 4 letter c of Law Number 16 Year 2017, must be mentioned in detail about the forms of understanding that are considered to be in conflict with Pancasila, for example:

What is meant by 'theory or understanding that is contrary to Pancasila' is the teachings of atheism, communism/marxism-Leninism, Khilafah understanding, ... and so on.

Furthermore, the explanation above continues by mentioning all notions that are considered to be in conflict with Pancasila, of course to be able to find any notions that are considered to be contrary to Pancasila must be done objectively through research conducted by involving elements of academia in it. So that in the past this kind of concept is more proportional and has a spirit of non-discrimination in terms of a juridical approach, because then if later there is a Community Organization or community groups feel disagreed that the understanding they profess is considered to be in conflict with Pancasila, then the Social Organization the person concerned can take legal steps in the form of filing a judicial review submitted to the Constitutional Court to obtain clarity and clarification from the Government and other legislators $^{12}$.

The weakness of the expansion of the Community Organization prohibition element is precisely in the design aspect of the Explanation section. In fact, Law Number 12 of 2011 concerning Formation of Regulations and Regulations limits the material content that can be included in the explanation section. Explanations should not include formulations that contain norms and formulas containing covert changes to the provisions of the legislation ${ }^{13}$. Article 59 paragraph (4) letter c Government regulations substituting for Social Organization Law actually formulate forms of prohibition for Community Organizations, one of which contains "Understanding that is contrary to Pancasila". Therefore, the explanation section should provide a concrete interpretation of the term: "Understanding that is contrary to Pancasila". However, the substance of the explanation actually expands the norms of Article 59 paragraph (4) letter c so that there are two additional elements of the expansion of meaning which are still very general interpretations and provide a multi-interpretation gap ${ }^{14}$.

\footnotetext{
${ }^{12}$ Victor Imanuel W. Nalle, Asas Contarius Actus Pada Perpu Organisasi Kemasyarakatan: Kritik Dalam Perspektif Hukum Administrasi Negara Dan Hak Asasi Manusia, Padjadjaran Jurnal Ilmu Hukum Volume 4 Nomor 2 Tahun 2017, p. 254

${ }^{13}$ Attachment of Law Number 12 of 2011 concerning Formation of Regulations and Regulations (Numbers 177 and 178).

${ }^{14}$ Victor Imanuel W. Nalle, Loc. Cit
} 


\section{c. Sociological Approach}

In Article 87 of the Criminal Code (KUHP). This article describes the forms of actions considered Makar, are as follows ${ }^{15}$ :

"It is said there is then to do an act, if the intention for that has turned out to be from the beginning of the implementation, as referred to in Article 53".

Furthermore Article 53 paragraph (1) explains ${ }^{16}$ :

"Trying to commit a criminal offense, if the intention for that has turned out to be from the beginning of the implementation, and not the completion of the implementation, is not solely due to his own will".

From the two articles, it can be understood that an act of treason must be preceded by an initial act, the concept used to measure whether there is intention or not. For this reason, the writer feels that the concept really needs to be adhered to by Law Number 16 Year 2017 as lex specialis for the Law of Social Organization to be able to prove that an understanding has teachings that are contrary to Pancasila.

The provisions of Article 59 paragraph (4) hurf c of Law Number 16 Year 2017 also basically relates to the provisions of Article 107 b, 107 c, and 107 d of Law Number 29 of 1999 concerning Amendments to the Indonesian Criminal Code. Crimes Against State Security, as follows ${ }^{17}$ :

Article $107 \mathrm{~b}$

Anyone who violates the law in public with oral, written from or through any media, expresses a desire to abolish or replace Pancasila as the basis of the country resulting in riots in society, or cause casualties or property losses, is convicted with the most imprisonment 20 years old.

Article $107 \mathrm{c}$

Anyone who violates the law in public by oral, written and or through any media, disseminates or develops the teachings of Communism/Marxism-Leninismce which results in riots in the community, or causes casualties or property losses, shall be punished with a maximum imprisonment of 15 year.

\section{Article $107 \mathrm{~d}$}

Anyone who violates the law in public by oral, written and or through any media, spreading or developing the teachings of Communism / Marxism-Leninism with the intention of changing or replacing Pancasila as the basis of the State, is sentenced to a maximum imprisonment of 20 years.

From the provisions above that need to be underlined is always to prioritize the concept of acts / actions in the implementation of the intended treason actions, both actions taken orally and in writing. So that the intended treason action is not solely against the inclusion of a certain understanding.

Therefore, from the above studies, to be able to find an objective measurement mechanism for "understanding that is contrary to Pancasila", there must be two important concepts in a socioligical approach, namely there must be a de jure and de facto measure of allegations "understanding that is contrary to Pancasila".

\footnotetext{
${ }^{15}$ Criminal Code (KUHP), Article 87

${ }^{16}$ Criminal Code (KUHP), Article 53 Paragraph (1)

${ }^{17}$ Indonesia, Law No. 29 of 1999 concerning Amendments to the Indonesian Criminal Code relating to Crimes Against State Security, Articles 107 B, 107 C, and 107 D.
} 
Conceptually according to the author's view, crime activities against state security consist of 3 forms, including:

1) Violent attack, what is meant by treason actions are activities that are undermining constitutionally legitimate government, which forms such as, the act of killing the President or Vice President, threatening the integrity and unity of the nation and state of Indonesia, and the act of overthrowing a legitimate government.

2) Subversive action, what is meant by subversive action is a manifestation of conflicting interests which cannot be met ("bijgelegd"), a continuation of political struggle by damaging the opposing forces in closed ways (covert), often also accompanied or followed by open acts of violence (war, rebellion) (explanation of the Subversive Law). The difference with treason is that subersive actions are seen more as a movement to disrupt state security but involve elements of external power such as political power or foreign intervention.

3) Act of rebellion, simply act of rebellion is an act whose initial form is a subversive act, but in the end it turns into a violent movement and even there is the use of weapons, so that this kind of action is no longer interpreted as subversive but rebellion.

Therefore, the use of the concept of understanding that is contrary to the Pancasila and its explanation points in Article 59 paragraph (4) letter c of Law Number 16 Year 2017 has its own differences and is not included in the 3 forms of acts towards state security as the author explained above.

This concept makes the judicial proof of violation of Article 59 paragraph (4) letter c has its own constraints because there are still explanations that are too general in nature. For this reason, the authors suggest several concepts, including:

1) Whereas the last explanation point in Article 59 paragraph (4) letter c of Law Number 16 Year 2017, especially containing the phrase "understanding aimed at changing / replacing Pancasila and the 1945 Constitution" can be replaced with the phrase "understanding which is subversive and aims rebellion ". So that all the points of limiting subversive actions contained in Presidential Decree No. 11 of 1963 can be used as a limitation. So that it does not occur multiple interpretations.

2) That the adoption of "understanding contrary to Pancasila" based on Article 59 paragraph (4) of Law Number 16 Year 2017, must be proven by two methods, namely de jure and de facto. That must be the beginning of activities that are contrary to the Pancasila carried out by certain Community Organizations.

\section{Competent Institutions Judging an Understanding is Conflicted with Pancasila}

The author will examine in 3 (three) important sources, namely: the Constitution (1945 Constitution), the Law on Judicial Power, and the Decision of the Constitutional Court .

First, in the 1945 Constitution of the Republic of Indonesia, in Chapter IX Article 24, it is explained that ${ }^{18}$ :

\footnotetext{
${ }^{18}$ Indonesia, 1945 Constitution, Chapter IX Article 24
} 
1) Judicial power is an independent power to administer justice to uphold law and justice.

2) Judicial power is exercised by a Supreme Court and the judiciary below it in the general court, religious court, military court, state administration court, and by a Constitutional Court.

3) Other institutions whose functions are related to judicial authority are regulated in the law.

In the concept of state institutions according to the 1945 Constitution, that there are two institutions that are given authority as a judicial institution that functions as an institution that carries out the function of judging in the concept of trias politica, namely the Supreme Court with the judicial institution below, and by the Constitutional Court.

However, in this study the author emphasizes that the authority to prosecute Community Organizations that violate them, should be left to the authority of the Supreme Court and the general judicial institutions underneath. The question arises then what about the MK?

Secondly, in Law Number 48 of 2009 concerning Judicial Power, Article 18 explains that ${ }^{19}$ : Judicial power is exercised by a Supreme Court and the judiciary below it within the general court, religious court, military court, state administrative court, and by a Constitutional Court. including ${ }^{20}$ :

Furthermore, Article 20 paragraph (2) explains that, the Supreme Court has several authorities,

The Supreme Court has the authority:

a) adjudicate at the level of appeal against decisions rendered at the final level by courts in all judicial environments that are under the Supreme Court, unless the law otherwise stipulates;

b) examine the statutory provisions under the law against the law; and

c) other authorities granted by law.

In the regulation on the authority of the Supreme Court above, it gives a lot of space, so that the authority of the Supreme Court can be expanded at any time with the note that the authority must be delegated by Law, which of course is not only the Law of Judicial Authority but other existing Laws to do with it.

Furthermore, in Article 5 of Law Number 48 of 2009 concerning Judicial Power, explains that ${ }^{21}$ : Judges and constitutional justices are required to explore, follow and understand the legal values and sense of justice that lives in society.

This article implicitly emphasizes that the judiciary as the executor of judicial power is the only one who has the right of interpretation of legal values both contained textually in the Law and abstractly living in society.

In the provisions of the prohibition of Community Organizations contained in Article 59 of Law Number 16 of 2017, especially related to "Understanding that is contrary to Pancasila", is very laden with nuances of social and moral values, therefore to be able to measure actions or understandings that are deemed contrary to that, it must be submitted to the judiciary in evaluating it.

\footnotetext{
${ }^{19}$ Indonesia, Law No. 48 of 2009 concerning Judicial Power, Article 18

${ }^{20}$ Ibid. Article 20 Paragraph (2)

${ }^{21}$ Ibid. Article 5
} 
Based on the aforementioned provisions it is clear that the court has an important position in the legal system of the Unitary Republic of Indonesia, because the Court performs functions which in essence complement the written legal provisions through legal formation (rechtsvorming) and legal discovery (rechtsvinding). In other words, judges/courts in the Indonesian legal system which primarily prioritizes the written have the function of making a new law (creation of new law). Therefore the Indonesian legal system, even though it is a written legal system, is an open system. ${ }^{22}$

Third, in the considerations of the Constitutional Court's decision 6-13-20/ PUU-VIII/2010 which confirms that deprivation or restriction of civil liberties in the form of prohibition, which is carried out absolutely by the government, without going through a judicial process, is an act of the power state, not the state a law like Indonesia as affirmed in Article 1 paragraph (3) of the 1945 Constitution that the state of Indonesia is a state of law. The Constitutional Court also said, the act of prohibition or restriction on civil liberties, "... especially without going through a judicial process, is an extra judicial execution that is strongly opposed in a rule of law that requires due process of law. Due process of law as considered above, is law enforcement through a justice system ". ${ }^{23}$

\section{Conclusions}

The prohibited phrase for Social Organizations to adhere to "understanding that is contrary to Pancasila" is regulated in Article 59 paragraph (4) letter c of Law Number 16 Year 2017 concerning the Establishment of Laws in Lieu of Law Number 2 of 2017 concerning Amendment to Law No 17 The year 2013 concerning Social Organization, which in its explanation stated that what is meant by "teachings or understandings that are contrary to Pancasila" include teachings of atheism, communism/marxismleninism, or other ideas aimed at replacing/changing Pancasila and the Constitution of the Republic of the Republic Indonesia in 1945.

To be able to find an objective measure of "understanding that is contrary to Pancasila", several approaches can be used namely, first the Philosophical approach, which focuses on theoretical deepening of the rule of law with the core of the study explaining that an Act must emerge with the principle of concrete rules and is easily understood in general, both textually and contextually must be able to understand its goals by society in general. Whereas in the approach of interpreting the law, it displays all limitations by looking at both grammatically and conceptually defining the elements of Article 59 paragraph (4) letter c. Secondly, the Juridical approach which explains that the mention of the last two additional elements in the explanation of Article 59 paragraph 4 letter c of Law Number 16 Year 2017, must be mentioned in detail about the forms of understanding deemed contrary to Pancasila. And third, a sociological approach that explains that to be able to find an objective measurement mechanism for "understanding that is contrary to Pancasila", there must be two important concepts in the socioligis of the writer, namely there must be a de jure and de facto measure of the alleged "understanding that is contrary to Pancasila ".

In the provisions of the prohibition of Community Organizations contained in Article 59 of Law Number 16 of 2017, especially related to "Understanding that is contrary to Pancasila", is very laden with

\footnotetext{
${ }^{22}$ Enju Juanda, Konstruksi Hukum Dan Metode Interpretasi Hukum, Jurnal Hukum Volume 4 No. 2 Septtember 2016 , p. 156

23 Decision of the Constitutional Court 6-13-20/PUU-VIII/2010 Concerning the Testing of Law Number 16 Year 2004 concerning the Attorney General's Office of the Republic of Indonesia and Law Number 4/PNPS/ 1963 Concerning the Safeguard of Printed Matter That Interferes with Public Order. P. 7
} 
nuances of social and moral values, therefore to be able to measure actions or understandings that are deemed contrary to that, it must be submitted to the judiciary in evaluating it. Institutions that are given the authority to assess the actions of Community Organizations as well as the prohibition points described in Article 59, must involve the role of the judiciary.

\section{Recommendations}

To the House of Representatives and the President, to immediately revise some of the provisions in Law No. 16 of 2017 concerning the Stipulation of Regulation in Lieu of Law No. 2 of 2017 concerning Amendment to Law No. 17 of 2013 concerning Community Organizations, specifically regarding the explanation point of Article 59 paragraph (4) letter c, so that the sound of the explanation then mentions in detail the notions which are considered to be in conflict with Pancasila, or at least replaces explanatory points that read "understanding that can change/replace Pancasila and the 1945 Constitution" by stating what notions are considered to be contrary to Pancasila, so that there is no longer any interpretation of the sound of the explanation of Article 59 paragraph (4) letter c

\section{References}

\section{Book}

A, M. Romly, Agama Menentang Komunisme, Bina Rena Pariwara, Jakarta, 1997;

Astim Riyanto, Teori Konstitusi, Yapemdo, Bandung, 2000,;

Azhary, Tahir, Negara Hukum Indonesia, Analisis Yuridis Normatif Tentang Unsur-Unsurnya, Ui Press, Jakarta, 1995;

Bambang Arwanto, "Perlindungan Hukum Bagi Rakyat Akibat Tindakan Faktual Pemerintah", Jurnal Yuridika Vol. 31 No. 3 September 2016;

Dani Vardiansyah, Filsafat Ilmu Komunikasi: Suatu Pengantar, Indeks, Jakarta 2008;

Enju Juanda, Konstruksi Hukum Dan Metode Interpretasi Hukum, Jurnal Hukum Volume 4 No. 2 Septtember 2016;

Erdi Rujikartawi, Komunis: Sejarah Gerakan Sosial Dan Idiologi Kekuasaan, Jurnal Qathrunâ, Vol. 2 No. 2 Juli-Desember, 2015;

F. Budi Hardiman, Melampaui Positivisme Dan Modernitas, Kanisius, Yogyakarta, 2003;

Gunawan A Tahuda, Komisi Negara Independen, Genta Press, Yogyakarta, 2012;

Hamzah Halim , Persekongkolan Rezim Politik Lokal, Jakarta: Pukap Cetakan Pertama 2009. 


\section{Regulation}

Indonesia, the 1945 Constitution of the Republic of Indonesia;

Indonesia, Law Number 8 of 1985 Concerning Community Organizations, Statute Book Number 44 of 1985, Supplement to Statute Book Number 3298;

Indonesia, Law No. 17 of 2003 concerning Social Organization, State Gazette Number 116 of 2013, Additional State Gazette Number 5430;

Indonesia, Law No. 48 of 2009 concerning Judicial Power;

Indonesia, Law Number 16 Year 2017 Concerning Establishment of Government Regulation in lieu of law on Community Organizations, State Gazette Number 239 Year 2017, Supplement to State Gazette Number 6139;

Indonesia, Government Regulation in lieu of law Number 2 of 2017 concerning Community Organizations, State Gazette Number 138 of 2017, Supplement to State Gazette Number 6084;

Decision of the Constitutional Court 6-13-20 / Puu-Viii / 2010 Concerning the Testing of Law Number 16 of 2004 concerning the Attorney General's Office of the Republic of Indonesia and Law Number 4 / Pnps / 1963 Concerning the Safeguard of Printed Goods that Interferes with Public Order.

\section{Internet}

Bem Kema Unpad "Perppu Organisasi Kemasyarakatan: Pemerkosaan Terhadap Hukum”, Https://Www.Selasar.Com/Jurnal/36674/Perppu-Organisasi Kemasyarakatan-PemerkosaanTerhadap-Hukum, Accessed 6 April 2019;

Fisal Ismail, Mengapa Marxisme-Komunisme-Leninisme Bertentangan Dengan Pancasila, Makalah Lepas Dalam Https://Nasional.Sindonews.Com/Read/1245228/18/Mengapa-MarxismeKomunisme-Leninisme-Bertentangan-Dengan-Pancasila-1507083361, Downloaded on April 3, 2019;

Soedarmedi, Perppu Organisasi Kemasyarakatan Lurus Kenapa Harus Takut, Https://Seword.Com/Politik/Inilah-Isi-Perppu-Organisasi Kemasyarakatan-Nomor-2-Tahun2017-Isinya-Luar-Biasa-Fpi-Dan-Sejenisnya-Apa-Kabar-Nanti/, Accessed February 2, 2019;

\section{Copyrights}

Copyright for this article is retained by the author(s), with first publication rights granted to the journal.

This is an open-access article distributed under the terms and conditions of the Creative Commons Attribution license (http://creativecommons.org/licenses/by/4.0/). 